\title{
Az uniós jog nemzeti büntetőjogra gyakorolt hatásai
}

\author{
európai büntetőjog - asszimilációs elv - büntetőjogi jogharmonizáció - \\ EUMSZ. 83. cikk - EUMSZ. 325. cikk
}

A 2009. december 1-jén hatályba lépett Lisszaboni Szerződéssel az európai integráció történetében először önálló, homogén, szupranacionális uniós politikává vált a büntetőjogi együttmüködés. Ennek ellenére nem lehet azonban azt mondani, hogy a közösségi/uniós jog és a nemzeti büntetőjog a Lisszaboni Szerződés hatálybalépését megelőzően teljesen független lett volna egymástól. Az uniós jog és a nemzeti jog számos ponton kapcsolódik egymáshoz, így a büntetőjog vonatkozásában is számos ponton figyelhetünk meg kölcsönhatást a két jogterület között. Az uniós jognak a tagállamok büntetőjogára gyakorolt hatása kétirányú: negatív és pozitív kötelezettségeket ró a tagállamokra. ${ }^{1}$

\section{Negatív hatás}

A negatív irányú (dekriminalizációs) kötelezettség azzal jár, hogy a tagállamok büntetőjogának azon részei, amelyek az uniós joggal összeegyeztethetetlenek, az uniós jog elsőbbségének elve ${ }^{2}$ alapján a bíróság előtti konkrét ügyben nem alkalmazhatók. Ilyenkor az uniós jog semlegesíti ${ }^{3}$ a nemzeti jogot, a belső jogi normák helyébe az uniós normák lépnek. ${ }^{4}$ Az uniós jog elsőbbségének elve alkalmazási elsőbbséget, nem pedig érvényességi elsőbbséget jelent. Az utóbbi eset ugyanis azt

* Dr. Udvarhelyi Bence tudományos segédmunkatárs, Miskolci Egyetem Állam- és Jogtudományi Kar Büntetőjogi és Kriminológiai Tanszék, jogbence@uni-miskolc.hu.

1 Herlin-Karnell, Esther: The Constitutional Dimension of European Criminal Law. Hart Publishing, OxfordPortland, 2012, 16-19; HoLÉ Katalin: Büntető anyagi és eljárási jogunk, valamint az Európai Unió kívánalmai. Magyar Jog, 2003/3, 141; LIGETı Katalin: Büntetőjog és bünügyi együttmüködés az Európai Unióban. KJK-Kerszöv, Budapest, 2004, 161-162.

2 6/64. sz., Costa kontra E.N.E.L. ügyben 1964. július 15-én hozott ítélet (ECLI:EU:C:1964:66); 11/70. sz., Internationale Handelsgesellschaft $\mathrm{mbH}$ kontra Einfuhr- und Vorratsstelle für Getreide und Futtermittel ügyben 1970. december 17-én hozott ítélet (ECLI:EU:C:1970:114), 3. pont; 106/77. sz., Amministrazione delle finanze dello Stato kontra Simmenthal ügyben 1978. március 9-én hozott ítélet (CLI:EU:C:1978:49), 17, 21-24. pont.

3 Delmas-Marty, Mireille: The European Union and Penal Law. European Law Journal, Vol. 4/1, 1998, 90-97.

4 Corstens, Geert-Pradel, Jean: European Criminal Law. Kluwer Law International, The Hague-LondonNew York, 2002, 505-506. 
jelentené, hogy az uniós joggal ellentétes nemzeti jogi normák automatikusan érvényüket vagy hatályukat vesztenék. Ezzel ellentétben az uniós jog elsőbbségének az elve mindössze az uniós jogba ütköző norma konkrét ügyben való alkalmazhatóságát zárja ki, az érvényességét és hatályát nem érinti. Ez azt jelenti, hogy az uniós joggal ellentétes jogi norma továbbra is érvényes, hatályos, és az uniós relevanciával nem bíró jogviszonyokra nézve alkalmazható marad. ${ }^{5}$

A nemzeti büntetőjog alkalmazhatatlanná nyilvánítására kizárólag akkor kerülhet sor, amennyiben az érintett belső norma az uniós jog valamely közvetlenül alkalmazható normájába ütközik. A közvetlenül alkalmazható uniós norma lehet elsődleges vagy másodlagos jogforrás. Az elsődleges jog területén mindenekelőtt az uniós jog alapelveit (például az arányosság elvét ${ }^{6}$ vagy a diszkrimináció tilalmát ${ }^{7}$ ), illetve az alapvető szabadságokat (áruk szabad mozgása, a személyek szabad mozgása, a letelepedés és szolgáltatás szabadsága, a tőke szabad mozgása) ${ }^{8}$ érintő szerződéses rendelkezések játszanak fontos szerepet. A másodlagos jogforrások közül a rendeletek azok, amelyek valamennyi tagállamban automatikusan közvetlenül alkalmazhatók és közvetlenül hatályosak, viszont az Európai Bíróság joggyakorlata alapján ${ }^{9}$ kivételes esetben ${ }^{10}$ az irányelvek is rendelkezhetnek közvetlen hatállyal. ${ }^{11}$

Az uniós jog nemzeti büntetőjogot semlegesítő hatása az Európai Unió Bíróságának joggyakorlatában is megjelent, a Bíróság számos olyan ítéletet hozott, amelyben alkalmazhatatlanná nyilvánította az uniós jog alapelveit (például az arányosság elvét, ${ }^{12}$ a diszkrimináció tilalmát ${ }^{13}$ ) vagy az alapvető szabadságokat sértő tagállami

5 Bővebben lásd ESSER, Robert: Europäisches und Internationales Strafrecht. C. H. Beck Juristischer Verlag, München, 2014, 9; HECKER, Bernd: Europäisches Strafrecht. Springer, Berlin-Heidelberg, 2012, 292-293; HEGER, Martin: Einwirkungen des Europarechts auf das nationale Strafrecht. In: Böse, Martin (Hrsg.): Europäisches Strafrecht mit polizeilicher Zusammenarbeit. Nomos, Baden-Baden, 2013, 207-208; SAFFERLING, Christoph: Internationales Strafrecht. Strafanwendungsrecht - Völkerstrafrecht - Europäisches Strafrecht. Springer, Heidelberg-Dordrecht-London-New York, 2011, 448.

6 EUSZ 5. cikk (4) bekezdés.

7 EUMSZ 18-19. cikk.

8 EUMSZ 28-37, 45-66. cikk.

9 41/74. sz., Van Duyn kontra Home Office ügyben 1974. december 4-én hozott ítélet (ECLI:EU:C:1974:133); 152/84. sz., Marshall kontra Southampton and South-West Hampshire Area Health Authority ügyben 1986. február 26-án hozott ítélet (ECLI:EU:C:1986:84).

10 Az irányelvek ún. vertikális közvetlen hatállyal rendelkeznek, ami azt jelenti, hogy a közvetlen hatály elve csak a tagállam és az állampolgár viszonyában érvényesül, a magánszemélyek egymás közötti horizontális viszonyában nem. Az irányelv közvetlen hatályára a magánfél akkor hivatkozhat, ha az implementációra rendelkezésre álló határidő lejárt, vagy ha a tagállam az irányelv rendelkezéseit nem megfelelően ültette át. További feltétel, hogy az irányelv kellően egyértelmü, pontos és feltétel nélküli rendelkezéseket tartalmazzon, amelyek a magánszemélyek számára valamilyen jogot alapítanak. Lásd: SAFFERLING: i. m., 466.

11 Esser: i. m., 9-10; Heger: i. m., 208; SATZger, Helmut: Internationales und Europäisches Strafrecht. Strafanwendungsrecht - Europäisches Straf- und Strafverfahrensrecht - Völkerstrafrecht. Nomos, Baden-Baden, 2013, 146.

12 Lásd például: 203/80. sz., Casati-ügyben 1981. november 11-én hozott ítélet (ECLI:EU:C:1981:261).

13 Lásd például: 63/83. sz., Kirk-ügyben 1984. július 10-én hozott ítélet (ECLI:EU:C:1984:255); 299/86. sz., Drexl-ügyben 1988. február 25-én hozott ítélet (ECLI:EU:C:1988:103). 
büntetőjogi normákat. ${ }^{14}$ A Bíróság e gyakorlata érintette a büncselekménnyé nyilvánítást, ${ }^{15}$ a büntetőjogi felelősséget, ${ }^{16}$ valamint a büntetés fajtáját és mértékét ${ }^{17}$ is. ${ }^{18}$

Vizsgáljuk meg az uniós jog dekriminalizációs hatását az Európai Bíróság Rattiügyben hozott döntésének példáján keresztül. Az előzetes döntéshozatali eljárás alapjául szolgáló tényállás szerint Tullio Ratti azért fordult bírósághoz, mert olyan magatartás miatt indítottak büntetőeljárást ellene, amelyet az olasz jog tiltott, viszont uniós irányelvek lehetővé tettek. Az olasz jogszabályok szerint ugyanis a veszélyes készítmények csomagolásán nemcsak azt kell feltüntetni, hogy ilyen anyagot tartalmaz, hanem azt is, hogy milyen arányban. A vonatkozó közösségi jogi szabályozás azonban ezt nem követelte meg. ${ }^{19}$ Mivel jelen esetben nyilvánvaló ellentmondás állt fenn a közösségi és olasz belső jog között, a két szabályozás közül a közösség irányelvei élveznek elsőbbséget, még akkor is, ha a tagállam elmulasztotta a belső jogát azok rendelkezéseihez igazítani. Így tehát az olasz jog a közösségi jog szabályaiba ütközött, ami miatt az a konkrét ügyben nem volt alkalmazható. ${ }^{20}$

\section{Pozitív hatás}

Az uniós jog nemzeti büntetőjogra gyakorolt pozitív hatása megvalósulhat az uniós és a nemzeti jog egymásra utalása útján, amelynek két típusa van. Egyfelől az uniós jog közvetlenül utalhat a tagállamok büntetőjogi rendelkezéseire, és előírhatja, hogy a nemzeti büntetőjogi tényállások hatályát terjesszék ki a szupranacionális, uniós jogtárgyak védelmére is (asszimiláció elve). Másfelől a nemzeti jog is visszautalhat az uniós jogra, amikor valamely büntetőjogi tényállást egy uniós norma tölt ki tartalommal (kerettényállások). ${ }^{21}$

$A z$ uniós jog emellett direkt befolyást is gyakorolhat a nemzeti büntetőjogokra, mivel az uniós jogalkotó a tagállamok büntetőjogának közelítését célzó intézkedéseket fogadhat el (jogharmonizáció), illetve a tagállamokban közvetlenül alkalmazandó büntetőjogi normákat is alkothat (szupranacionális büntetőjog-alkotási hatáskör).

14 LIGETI: i. m., 166-167.

15 Lásd például: 148/78. sz., Ratti-ügyben 1979. április 5-én hozott ítélet (ECLI:EU:C:1979:110); 5/83. sz., Rienks-ügyben 1983. december 15-én hozott ítélet (ECLI:EU:C:1983:382).

16 Lásd például: 25/88. sz., Wurmser és társai ügyben 1989. május 11-én hozott ítélet (ECLI:EU:C:1989:187).

17 Lásd például: 67/74. sz., Bonsignore kontra Oberstadtdirektor der Stadt Köln ügyben 1975. február 26-án hozott ítélet (ECLI:EU:C:1975:34); 30/77. sz., Regina kontra Bouchereau ügyben 1977. október 27-én hozott ítélet (ECLI:EU:C:1977:172).

18 Bővebben lásd FARKAs Ákos: Büntetőjogi együttmüködés az Európai Unióban. Osiris Kiadó, Budapest, 2001, 11-21.

19 KARSAI Krisztina: Magyar büntetőjog az európai integráció sodrában. Jogtudományi Közlöny, 2002/2, 85-86.

20 148/78. sz., Ratti-ügyben hozott ítélet, 17, 22-24. pont.

21 SATZger, Helmut: Europäisierung. In: Sieber, Ulrich-Brüner, Franz-Hermann-Satzger, Helmut-v. HeintschelHeinegg, Bernd (Hrsg.): Europäisches Strafrecht. Nomos, Baden-Baden, 2011, 234. 


\subsection{Az asszimilációs kötelezettség}

Az uniós jogból eredő pozitív irányú kötelezettség egyrészt a szupranacionális, uniós jogtárgyak tagállami büntetőjog általi védelmének megteremtését vonja maga után. A tagállamok ez irányú kötelezettsége az uniós hüség vagy más néven a lojális együttmüködés elvéböl vezethető le. A lojalitási alapelv alapján az Unió és a tagállamok kölcsönösen tiszteletben tartják és segítik egymást a szerződésekből eredő feladatok végrehajtásában (együttmüködési kötelezettség), a tagállamok megteszik a megfelelö általános vagy különös intézkedéseket a szerződésekböl, illetve az Unió intézményeinek intézkedéseiből eredő kötelezettségek teljesítése érdekében, és segítik az Uniót feladatainak teljesítésében (cselekvési kötelezettség), valamint tartózkodnak minden olyan intézkedéstől, amely veszélyeztetheti az Unió célkitűzéseinek megvalósítását (tartózkodási kötelezettség). ${ }^{22}$

A hüség klauzulából a tagállamra háramló kötelezettségeket az Európai Bíróság a görög kukorica ügyben fejtette ki részletesen. Ítéletében a Bíróság arra a következtetésre jutott, hogy az uniós hüség elve értelmében a tagállamok kötelesek a közösségi jogi jogsértések elkövetöit ugyanúgy szankcionálni, mint a nemzeti jogi jogsértések elkövetöit. A szankciók megválasztásának a joga a tagállamokat illeti meg, akiknek azonban ügyelniük kell arra, hogy a közösségi jog megsértését hasonló anyagi jogi és eljárásjogi feltételek mellett szankcionálják, mint a nemzeti jogot sértő, hasonló jellegü és jelentőségű cselekményeket, valamint arra, hogy a szankciók egyébként hatékonyak, arányosak és visszatartó erejüek legyenek. A nemzeti hatóságoknak továbbá ugyanazzal a gondossággal és körültekintéssel kell eljárniuk a közösségi jog megsértésének eseteiben, mint ahogyan az azoknak megfelelő nemzeti jogszabályok alkalmazása során eljárnak. ${ }^{23}$

A görög kukorica ügyben deklarált asszimiláció elve tehát arra kötelezi a tagállamokat, hogy nemzeti (büntető-) jogukat az uniós érdekek hatékony végrehajtásának szolgálatába állitsák, ${ }^{24}$ és a nemzeti jogtárgyaikat védő tényállásaik hatályát a hasonló jellegü és jelentőségü ${ }^{25}$ uniós jogtárgyakra is kiterjesszék. ${ }^{26} \mathrm{Az}$ asszimiláció elvéből ugyanakkor nem következik feltétlenül a büntetőjogi eszközök alkalmazá-

22 EUSZ 4. cikk (3) bekezdés (korábban EGK Szerződés 5. cikk, majd az Amszterdami Szerződést követően EK Szerződés 10. cikk).

23 68/88. sz., Bizottság kontra Görögország ügyben 1989. szeptember 21-én hozott ítélet (ECLI:EU:C:1989:339), 22-25. pont. Ezeket a tételeket a Bíróság számos további ügyben is megerősítette. Lásd például 326/88. sz., Hansen-ügyben 1990. július 10-én hozott ítélet (ECLI:EU:C:1990:291), 17. pont; C-382/92. sz., Bizottság kontra Egyesült Királyság ügyben 1994. június 8-án hozott ítélet (ECLI:EU:C:1994:233), 55. pont; C-352/92. sz., Milchwerke Köln/Wuppertal kontra Hauptzollamt Köln-Rheinau ügyben 1994. július 14-én hozott ítélet (ECLI:EU:C:1994:294), 23. pont; C-186/98. sz., Nunes és de Matos ügyben 1999. július 8-án hozott ítélet (ECLI:EU:C:1999:376), 9-12. pont.

24 Hugger, Heiner: The European Community's Competence to Prescribe National Criminal Sanctions. European Journal of Crime, Criminal Law and Criminal Justice, Vol. 3/3, 1995, 247; Mennens, Emile: Fraud on the Financial Interests of the Community. In: Delmas-Marty, Mireille (ed.): What Kind of Criminal Policy for Europe? Kluwer Law International, The Hague-London-Boston, 1996, 141.

25 Lásd HECKER (2012): i. m., 237-238.

26 Амвоs, Kai: Internationales Strafrecht. Strafanwendungsrecht - Völkerstrafrecht - Europäisches Strafrecht - Rechtshilfe. C. H. Beck, München, 2014, 567; SAFFERLING: i. m., 459. 
sa. ${ }^{27} \mathrm{~A}$ tagállamok kötelesek ugyan megteremteni az uniós jogtárgyak nemzeti jogtárgyakkal azonos szintű védelmét, ${ }^{28}$ amit mind az anyagi jogi, mind az eljárásjogi szabályokkal, mind pedig az eljárási praxissal ${ }^{29}$ biztosítaniuk kell, annak megválasztásában viszont, hogy ezt az azonos szintű védelmet közigazgatási vagy büntetőjogi szankciókkal teremtik meg, szabad kezet kapnak, mindössze arra kell tekintettel lenniük, hogy a kiválasztott szankció hatékony, arányos és visszatartó erejü legyen. Ebből viszont az is következik, hogy ha az adott jogtárgy a belső jogban büntetőjogi védelemben részesül, akkor az azonos uniós jogtárgy megsértését is büntetőjogi eszközökkel kell szankcionálni. ${ }^{30}$ Ebben az esetben az asszimiláció elve kifejezett kriminalizációs kötelezettséget ró a tagállamokra.

Az asszimiláció elvének alkalmazása pusztán az uniós és a nemzeti jogtárgyak védelme közötti különbségeket számolja fel, de nem jár a tagállamok nemzeti jogainak harmonizációjával, egymáshoz közelítésével. Éppen ezért az asszimilációs kötelezettség a jogharmonizációhoz képest egy vonzóbb, a nemzeti szuverenitást jobban figyelembe vevő alternatívát kínál a tagállamok számára, mivel minden állam a saját megoldását alkalmazhatja a szupranacionális jogtárgyak védelmére, nem kell semmilyen idegen, harmonizált szabályozást elfogadnia. Épp ez jelenti az elv hátrányát is, hiszen ha minden állam a saját nemzeti jogát terjeszti ki az uniós jogtárgyak védelmére, akkor a nemzeti és uniós jogtárgyak védelme ugyan hasonló lesz, de ez a nemzeti jogok közötti különbségeket nem küszöböli ki, így az uniós jogtárgy védelme továbbra is tagállamonként eltérő szintű lesz. Problémát jelent továbbá, hogy az asszimiláció nem alkalmazható, ha a belső jogból hiányzik az összehasonlítható jogi tárgy, vagyis ha a nemzeti jog az adott szupranacionális jogtárgy tagállami megfelelőjét nem vagy nem megfelelően védi. ${ }^{31}$ Ennek a hátránynak a kiküszöbölése érdekében rögzítette a Bíróság a szankciók hármas minimumkövetelményét, amelynek értelmében az uniós jog megsértőit hatékony, arányos és visszatartó erejü szankciókkal kell sújtani. ${ }^{32}$ Mivel ezeket a kritériumokat valamennyi tagállam szankciórendszerének követnie kell, így az Európai Bíróság ítélete végső soron a nemzeti jog egyfajta minimumharmonizációját ${ }^{33}$ is magában hordozza.

27 Delmas-Marty: i. m., 105. Vesd össze: C-7/90. sz., Vandevenne és társai ügyben 1991. október 2-án hozott ítélet (ECLI:EU:C:1991:363), 11-12. pont.

28 DANNECKER, Gerhard: Strafrechtlichen Schutz der Finanzinteressen der Europäischen Gemeinschaft gegen Täuschung. Zeitschrift für die gesamte Strafrechtswissenschaft, 3/1996, 585; RüTER, C. Frederik: Harmonie trotz Dissonanz. Gedanken zur Erhaltung eines funktionsfähigen Strafrechts im grenzenlosen Europa. Zeitschrift für die gesamte Strafrechtswissenschaft, 1/1993, 42-43.

29 KARSAI Krisztina: Az európai büntetőjogi integráció alapkérdései. KJK-Kerszöv Kiadó, Budapest, $2004,103$.

30 KARSAI Krisztina: Az Európai Bíróság szerepe az európai büntetőjog alakításában. In: Kondorosi FerencLigeti Katalin (szerk.): Az európai büntetőjog kézikönyve. Magyar Közlöny Lap- és Könyvkiadó, Budapest, 2008, 724.

31 KaRSAI (2004): i. m., 44-45, 103-104.

32 HeCKER, Bernd: Harmonisierung. In: Sieber, Ulrich-Brüner, Franz-Hermann-Satzger, Helmut-v. HeintschelHeinegg, Bernd (Hrsg.): Europäisches Strafrecht. Nomos, Baden-Baden, 2011, 255; HEGER: i. m., 186.

33 Tiedemann, Klaus: Die Europäisierung des Strafrechts. In: Kreuzer, Karl F.-Scheuing, Dieter H.-Sieber, Ulrich (Hrsg.): Die Europäisierung der mitgliedstaatlichen Rechtsordnungen in der Europäischen Union. Nomos, Baden-Baden, 1997, 143-144. 
A teljesség kedvéért fontos megjegyezni, hogy a tagállamok nem pusztán a közösségi hüség elvéből levezetve kötelezhetők az uniós jogtárgyak nemzeti joggal azonos szintü védelmének biztosítására, mivel az asszimilációs kötelezettséget elsődleges és másodlagos jogforrások is elöírhatják.

Már az alapító szerződésekben is megjelennek olyan cikkek, amelyek az asszimilációs elv direkt megjelenítésének tekinthetők: ezek önálló közösségi büntetőjogi hatáskörök hiányában bizonyos közösségi jogtárgyakat sértő cselekmények üldözésére közvetlenül valamely nemzeti jogi szabályozást hívják fel. ${ }^{34}$ Ezek a normák a tagállamokat kötelezik, hogy a nemzeti büntetőjogukat és büntető eljárásjogukat úgy alakítsák ki és alkalmazzák, hogy az elsődleges jogforrásokban megjelölt jogtárgyak védelmét a nemzeti jogtárgyakkal azonos módon biztosítsák. ${ }^{35}$ Így az Európai Atomenergia Közösséget létrehozó Szerződés 194. cikk (1) bekezdése kimondja, hogy az atomtitok-védelmi szabályok megszegését valamennyi tagállam köteles a titokvédelmi szabályait sértő olyan cselekedetként kezelni, amelyre mind az alkalmazandó anyagi jog, mind a joghatóság tekintetében az állam biztonsága elleni cselekményekre vagy a hivatali titok megsértésére vonatkozó jogszabályait kell alkalmazni. Az Európai Unió Bírósága alapokmányának ${ }^{36} 30$. cikke értelmében pedig a Bíróság előtti hamis tanúvallomást vagy a hamis szakvélemény adását a tagállamok ugyanúgy kötelesek megítélni, mintha ezt a büncselekményt valamely polgári ügyekben hatáskörrel rendelkező bíróságuk előtt követték volna el. ${ }^{37}$

$A z$ elsődleges jogforrásokban megjelenő asszimilációs kötelezettségek köre a Maastrichti Szerződéssel ${ }^{38}$ bővült ki, amely átvette, és a Közösség pénzügyi érdekeit sértő csalások elleni küzdelem terén konkretizálta az Európai Bíróság görög kukorica ügyben kimondott tételeit. ${ }^{39}$ Az EUMSZ 325. cikk (2) bekezdésének hatályos szövege értelmében a tagállamok kötelesek megtenni ugyanazokat az intézkedéseket az Unió pénzügyi érdekeit sértő csalás leküzdésére, mint amelyeket a saját pénzügyi érdekeiket sértő csalások leküzdésére tesznek.

Az asszimilációs kötelezettséget előíró másodlagos uniós normák közül büntetőjogi relevanciája miatt a korrupció elleni küzdelem tárgyában született jogforrásokat érdemes kiemelni és példaként hozni. Az 1996-ban az Európai Közösség pénzügyi érdekeinek védelméről szóló egyezményhez csatolt első kiegészítő jegyzőkönyv ${ }^{40}$ 4. cikke, valamint az egy évvel később, 1997-ben aláírt korrupció elleni küzdelemről

34 KARSAI (2004): i. m., 119.

35 Esser: i. m., 18; SATZger (2011): i. m., 235-236.

36 A Lisszaboni Szerződéshez csatolt 3. jegyzőkönyv az Európai Unió Bíróságának alapokmányáról.

37 Bővebben lásd Amвos: i. m., 566-569; DAnNECKER, Gerhard: Einführung von Tatbeständen mit supranationaler Schutzrichtung. In: Böse, Martin (Hrsg.): Europäisches Strafrecht mit polizeilicher Zusammenarbeit. Nomos, Baden-Baden, 2013, 292-293; Esser: i. m., 18-20; HeCKer (2012): i. m., 220-223; Heger: i. m., 187-191; SATZger (2011): i. m., 234-236.

38 EK Szerződés 209a cikk, majd az Amszterdami Szerződést követően EK Szerződés 280. cikk (2) bekezdés.

39 DANNECKER (2013): i. m., 298; LÉVAI Ilona: Az európai jogi architektúra - büntetőjogászi nézőpontból. Ügyészek Lapja, 1998/5, 67; Mennens: i. m., 142; Murawska, Agnieszka Aleksandra: Administrative Anti-Fraud Measures within the European Union. Necessity and Means. Nomos, Baden-Baden, 2008, 65, 68; SAFFERLING: i. m., 400.

84 A Tanács jogi aktusa (1996. szeptember 27.) az Európai Közösségek pénzügyi érdekeinek védelméről szóló egyezményhez csatolt jegyzőkönyv létrehozásáról. HL C 313, 1996. 10. 23., 1-11. 
szóló egyezmény ${ }^{41} 4$. cikke lényegében egyező módon írja elő a tagállamoknak, hogy a közösségi hivatalos személyek által elkövetett korrupciós cselekményeket ugyanúgy büntessék, mint a saját nemzeti tisztviselöik által megvalósított vesztegetéseket. Eszerint a tagállamok kötelesek büntetni a közösségi szervek (Európai Bizottság, Európai Parlament, Európai Bíróság, Európai Számvevőszék) tagjai által vagy sérelmére elkövetett korrupciós cselekményeket is, amennyiben az adott állam belső joga is előírja a tagállami megfelelőik (miniszterek, parlamenti képviselők, a legfelsőbb bíróság, illetve a számvevőszék tagjai) korrupciós cselekmények miatti büntethetőségét. İgy tehát amennyiben valamely tagállamban egy nemzeti tisztviselő (pl. parlamenti képviselö) megvesztegetése büntetendő, a nemzeti jogalkotó köteles a büntetőjogi tényállás hatályát a posztjuknak megfeleltethető közösségi tisztviselők (európai parlamenti képviselők) korrupciós cselekményeire is kiterjeszteni. ${ }^{42}$

\subsection{A kerettényállások}

Az asszimiláció elvéhez hasonlóan a kerettényálláso $k^{43}$ is az uniós jogot sértő szándékos vagy gondatlan magatartások nemzeti büntetőjog alapján történő szankcionálását teszik lehetővé. ${ }^{44}$ Míg azonban az asszimilációs kötelezettség esetén az uniós jog utal - akár közvetlenül elsődleges jogforrás alapján, ${ }^{45}$ akár közvetett módon, az uniós hüség elvéből levezetve - a nemzeti jogra, addig a kerettényállásoknál fordított a helyzet. Ebben az esetben egy tagállami büntetőjogi norma utal vissza az uniós jogra oly módon, hogy a büntetendő magatartást részben vagy egészben a vonatkozó uniós normára hivatkozva határozza meg. ${ }^{46} \mathrm{~A}$ teljes büntetőjogi tényállást így a nemzeti blankettaszabály és az azt kitöltő uniós norma (rendelet vagy irányelv) együttesen adja meg. ${ }^{47}$

A keretdiszpozícióknak két alaptípusát különböztethetjük meg: statikus a keretdiszpozíció, ha az azt kitöltő uniós norma egy meghatározott időbeli állapotára, míg dinamikus, ha a vonatkozó uniós szabály mindenkor hatályos szövegváltozatára utal. Amíg tehát a statikus keretdiszpozíció esetén a nemzeti tényállást folyamatosan hozzá kell igazítani a módosuló uniós normához, addig a dinamikus kerettényállás esetén az uniós jog módosulása nem követeli meg a nemzeti jogalkotó aktív fellépését, hiszen a tagállami büntetőnorma automatikusan a megváltozott szövegre fog utalni. ${ }^{48}$

41 A Tanács jogi aktusa (1997. május 26.) az Európai Unióról szóló szerződés K.3. cikke (2) bekezdésének c) pontja alapján, az Európai Közösségek tisztviselöit és az Európai Unió tagállamainak tisztviselőit érintő korrupció elleni küzdelemről szóló egyezmény kidolgozásáról. HL C 195, 1997. 06. 25., 1-11.

42 VÉGVÁRI Réka: Vesztegetés. In: Kondorosi Ferenc-Ligeti Katalin (szerk.): Az európai büntetöjog kézikönyve. Magyar Közlöny Lap- és Könyvkiadó, Budapest, 2008, 462; ZEDER, Fritz: A büntetőjogi együttmüködés jogi aktusai az Európai Unióban és azok államon belüli átültetése. Magyar Jog, 1999/11, 685.

${ }^{43}$ Bár a magyar büntetőjogban az uniós jogra utaló kerettényállásokat nem igazán találunk, más tagállamokban, különösen Németországban ez egy elöszeretettel alkalmazott módszer.

44 HECKER (2012): i. m., 244.

45 Lásd EUMSZ 325. cikk (2) bekezdés, Euratom Szerződés 194. cikk (1) bekezdés, Európai Bíróság Alapokmánya 30. cikke.

46 Satzger (2011): i. m., 236.

47 Heger: i. m., 198.

48 Safferling: i. m., 472-474; Satzger (2011): i. m., 237. 
A kerettényállások kétségtelen előnye, hogy az uniós normára való utalással a büntetőjogi tényállás viszonylag egyszerüen, röviden és világosan megfogalmazható. A blankettáris szabályozás ugyanakkor komoly alkotmányjogi aggályokat is felvet. Azáltal, hogy a nemzeti jogalkotó valamely uniós normát a büntetőjogi tényállás tartalmi elemévé emeli, a kerettényállást kitöltő jogi norma is a tényállás részévé válik, aminek így ugyanúgy meg kell felelnie a büntetőjogi normákkal szemben támasztott követelményeknek. ${ }^{49} \mathrm{Az}$ alkotmányos aggályok elsősorban a dinamikus keretdiszpozíciók esetén merülnek fel, különösen a kitöltő norma gyakori módosítása esetén. llyenkor sérülhet a jogbiztonság és a törvényesség (nullum crimen sine lege, nulla poena sine lege) elve, azon belül is elsősorban a határozott büntetőjogi norma követelménye és a visszaható hatály tilalma. ${ }^{50}$

Statikus keretdiszpozíció esetén további problémát jelenthet az is, ha a nemzeti jogalkotó nem igazítja hozzá a büntetőjogi tényállást az időközben módosított uniós normához. Ez a probléma dinamikus blanketták esetén is fennállhat, ha a vonatkozó uniós normát hatályon kívül helyezik vagy megsemmisítik. Ilyenkor a nemzeti tényállás kiüresedik, mivel az egy már nem létező normára utal vissza. ${ }^{51}$

\subsection{Jogharmonizációs hatáskör}

A jogharmonizáció, más néven a jogközelítés fogalmilag a nemzeti jogrendszerek egyes különbözőségeinek valamilyen közös cél érdekében történő leépítését jelenti, egységes szabályok bevezetése nélkül. A büntetőjog területén a jogharmonizáció az egyes tagállamok büntetőjogi rendszerei közötti különbségek fokozatos kiküszöbölését célozza. ${ }^{52}$

A Lisszaboni Szerződés hatálybalépéséig heves viták folytak arról, hogy az Európai Közösség (az Európai Unió I. pillére) rendelkezik-e a büntetőjogi jogharmonizációs hatáskörökkel. A szakirodalmi álláspontok többsége elutasította az Európai Közösség büntetőjogi hatáskörének lehetőségét. ${ }^{53}$ Ennek alátámasztásául a hatáskör-átruházás elve ${ }^{54}$ szolgált, amelynek megfelelően az Európai Unió kizárólag a tagállamok által a szerződésekben ráruházott hatáskörök határain belül járhat el, és az olyan hatáskörök, amelyeket a szerződések nem ruháztak át kifejezetten az Unióra, a tagállamoknál maradnak. Mivel az EK Szerződés büntetőjogi rendelkezéseket nem tartalmazott, ezért a Közösség sem rendelkezett büntető jogkörrel. ${ }^{55}$

49 KaRSAl (2002): i. m., 84.

50 Bővebben lásd Esser: i. m., 38-41; Heger: i. m., 200-206; Satzger (2013): i. m., 138-144.

51 SATZger (2011): i. m., 241-242.

52 Karsal Krisztina: A jogharmonizáció általános tanai. In: Kondorosi Ferenc-Ligeti Katalin (szerk.): Az európai büntetőjog kézikönyve. Magyar Közlöny Lap- és Könyvkiadó, Budapest, 2008, 433-434.

53 Lásd például FletCHeR, Maria-LööF, Robin-GILMORE, Bill: EU Criminal Law and Justice. Edward Elgar Publishing, Cheltenham-Northampton, 2008, 175; Hugger: i. m., 243; Karsal (2004): i. m., 113; Ligeti: i. m., 160; RosenAu, Henning: Zur Europäisierung im Strafrecht. Vom Schutz finanzieller Interessen der EG zu einem gemeineuropäischen Strafgesetzbuch? Zeitschrift für Internationale Strafrechtsdogmatik, 1/2008, 9.

54 EK Szerződés 3b cikk, majd az Amszterdami Szerződést követően EK Szerződés 5. cikk, jelenleg EUSZ 5. cikk (1)-(2) bekezdés.

55 ZöLLER, Mark A.: Europäische Strafgesetzgebung. Zeitschrift für Internationale Strafrechtsdogmatik, 7/2009, 342. 
A kifejezett elsődleges jogforrási felhatalmazás ellenére azonban az Európai Közösség közvetett módon mégis hatott a tagállamok büntetőjogára. A Közösség számos olyan másodlagos jogforrást fogadott el, amelyben valamely közösségi jogtárgy védelmét úgy biztosították, hogy a tagállamok számára az adott jogsértés szankcionálását írták elő. ${ }^{56}$ Ilyen volt például a bennfentes kereskedelemrő/ ${ }^{77}$ vagy a pénzmosás elleni fellépésrő/158 szóló irányelv. Ezek az irányelvek részletesen meghatározták a tilalmazandó tényállásokat, amelyeket a tagállamok kötelesek voltak átvenni, azoktól nem térhettek el, azokat nem szükíthették le. ${ }^{59} \mathrm{~A}$ szankciók típusait azonban az irányelvek nem részletezték, annak megválasztását a tagállamokra hagyták, akik így szabadon eldönthették, hogy milyen módon szereznek érvényt az általuk előírt tilalmaknak. ${ }^{60}$ Látható tehát, hogy a másodlagos jogforrások sosem kriminalizációs, hanem pusztán szankcionálási kötelezettséget róttak a tagállamokra, mivel a tagállamok minden esetben szabadon választhattak, hogy a közösségi jogforrásban tiltott magatartást büntetőjogi vagy egyéb (közigazgatási, polgári jogi) szankciókkal kívánják-e sújtani.

Hogy nézett ki a Közösség jogharmonizációs gyakorlata az 1991-ben elfogadott, pénzmosás elleni irányelv példáján? Az irányelv meghatározta a pénzmosás tényállását, kötelezte a tagállamokat a pénzmosás megtiltására, és elöírta, hogy a tagállamok hozzák meg a „megfelelö intézkedéseket” az irányelv rendelkezéseinek nemzeti jogba való átültetésére és a szükséges szankciók megállapítására. ${ }^{61}$ Bár az irányelv szövege nem írta elő kifejezetten a büntetőjogi szankciók szükségességét, a preambulumban az uniós jogalkotó egyértelműen utalt arra, hogy a pénzmosás ellen mindenekelőtt a büntetőjog eszközeivel kell felvenni a harcot, amelyből világosan érződik a büntetőjog alkalmazására irányuló politikai akarat. ${ }^{62} \mathrm{Az}$ Európai Bizottság eredeti javaslata egyébként a pénzmosás büntethetővé nyilvánítását tartalmazta, amit azonban a Tanács nem támogatott, így született meg kompromisszumként az a megoldás, hogy a tagállamok mindössze tilalmazni kötelesek a pénzmosást, ami, mint láthattuk, nem jelent feltétlenül büntetőjogi szankcionálást. A Tanács óvatossága ellenére azonban a pénzmosást valamennyi uniós tagállamban büncselekménynek minősítették, így az irányelv a pénzmosás de facto kriminalizálásához,

56 Albrecht, Peter-Alexis-Braum, Stefan: Kontingentes »Europäisches Strafrecht in actio: Schwerpunkte, Konture, Defizite. Kritische Vierteljahresschrift für Gesetzgebung und Rechtswissenschaft, 3/2001, 333336; KaRSAI (2004): i. m., 133.

57 A Tanács 89/592/EGK irányelve (1989. november 13.) a bennfentes kereskedelemre vonatkozó rendelkezések összehangolásáról. HL L 334, 1989. 11. 18., 30-32.

58 A Tanács 91/308/EGK irányelve (1991. június 10.) a pénzügyi rendszerek pénzmosás céljára való felhasználásának megelőzéséről. HL L 166, 1991. 06. 28., 77-82.

59 LIGETI: i. m., 170-171.

60 PeERs, Steve: Büntetőjog. In: Lévay Miklós-Kígyóssy Katinka (szerk.): Az Európai Unió hatása a büntetőjog fejlődésére. Bíbor Kiadó, Miskolc, 2004, 152-153; Vervaele, John A. E.: The European Community and Harmonization of the Criminal Law Enforcement of Community Policy: Ignoti nulla cupido? In: Bassiouni, M. Cherif-Militello, Vincenzo-Satzger, Helmut (eds.): European Cooperation in Penal Matters: Issues and Perspectives. Casa Editrice Dott. Antonio Milani, Padova, 2008, 37.

61 91/308/EGK irányelv 1-2. és 14. cikk.

62 Albrecht, Peter-Alexis-Braum, Stefan: Deficiencies in the Development of European Criminal Law. European Law Journal, Vol. 5/3, 1999, 301. 
és így a pénzmosás tényállásának uniós szintủ meghatározása révén a tagállami büntetőjogok harmonizációjához vezetett. ${ }^{63}$

A puszta szankcionálási kötelezettséget elöíró irányelvek mellett az Európai Bizottság időről időre több olyan I. pilléres jogalkotási javaslatot is kezdeményezett, amely kifejezetten a tagállamok büntetőjogának harmonizációjára irányult volna. A Bizottság javaslatai azonban nem kerültek elfogadásra, mivel a Tanács vagy teljesen elutasította azt, vagy pedig az I. pilléres irányelv helyett III. pilléres jogforrás elfogadása mellett döntött. Emellett többször is elöfordult az ún. kettős jogalkotási mechanizmus, ${ }^{64}$ amelynek során a Tanács ugyanazon tárgykörben párhuzamosan két jogforrást is elfogadott, ilyenkor az I. pilléres irányelv határozta meg a szankcionálandó magatartást, míg a III. pilléres kerethatározat e magatartás büntetendővé nyilvánításáról és az alkalmazható szankciókról rendelkezett.

Az Európai Közösség hatáskörének hiányában a büntetőjogi jogharmonizáció elsődlegesen a Maastrichti Szerződéssel létrehozott III. pillérben zajlott. A bel- és igazságügyi együttmüködést az Európai Unió keretei közé bevonó Maastrichti Szerződés még nem tartalmazott olyan rendelkezést, amely kifejezetten jogharmonizációs hatáskörrel ruházta volna fel az Európai Uniót. ${ }^{65} \mathrm{~A}$ Szerződés az anyagi büntetőjogot érintően mindössze szükszavúan utalt arra, hogy a nemzetközi méreteket öltő csalás, a tiltott kábítószer-kereskedelem, a terrorizmus és a nemzetközi bünözés egyéb formái elleni küzdelem közös érdekü ügynek tekinthető. Ezeken a területeken a Tanács együttes álláspontokat és együttes fellépéseket fogadhatott el, illetve egyezményeket dolgozhatott ki. ${ }^{66} \mathrm{~A}$ kifejezett felhatalmazás hiánya ellenére a Szerződés hatálybalépését követően számos büntetőjogi jogközelítésre irányuló jogi aktus született.

Az 1999-ben hatályba lépett Amszterdami Szerződés legfontosabb célkitüzése egy, a polgárok magas szintű biztonságát garantáló, „a szabadságon, a biztonságon és a jog érvényesülésén alapuló térség” megteremtése. E célt az Európai Unió egyebek mellett a rasszizmus és idegengyülölet, valamint a szervezett vagy egyéb bünözés, így különösen a terrorizmus, az emberkereskedelem és a gyermekek sérelmére elkövetett büncselekmények, a tiltott kábítószer-kereskedelem és a tiltott fegyverkereskedelem, a korrupció és a csalás megelőzésével és az ezek elleni küzdelemmel valósítja meg. Ennek eszköze egyrészt a tagállamok rendőri szervei, vámhatóságai, igazságügyi hatóságai és egyéb, hatáskörrel rendelkező hatóságai közötti szorosabb együttmüködés megteremtése, másrészt pedig, ahol szükséges, a tagállamok büntetőjogi szabályainak közelitése ${ }^{67} \mathrm{Az}$ Amszterdami Szerződés ennek érdekében konkrét jogharmonizációs hatáskörrel ruházta fel az uniós jogalkotót a büntetőjog területén, amikor felhatalmazta a Tanácsot, hogy a szervezett bünözés, a terrorizmus és a tiltott kábitószer-kereskedelem területén szabályozási minimumokat határozzon meg a büncselekmények tényállási elemeire és a büntetési tételekre vonatkozóan. ${ }^{68}$

63 Mitsilegas, Valsamis: EU Criminal Law. Hart Publishing, Oxford-Portland, 2009, 66-67.

64 Lásd Fletcher-LöÖF-Gilmore: i. m., 176.

65 Peers, Steve: EU Justice and Home Affairs Law. Oxford University Press, Oxford-New York, $2011,755$.

66 EUSZ K.1. és K.3. cikk.

67 EUSZ 29. cikk.

68 EUSZ 31. cikk e) pont. 
Az Amszterdami Szerződéssel intézményesített jogharmonizációs hatáskör terjedelmének megítélése erősen vitatott volt. ${ }^{69}$ A 31 . cikk e) pontjában felsorolt büncselekmények köre ugyanis szükebb volt, mint amelyek ellen az Unió a 29. cikk alapján küzdeni akart. ${ }^{70} \mathrm{~A} 29$. cikkben rögzített büncselekményi katalógus ráadásul (terrorizmus, emberkereskedelem és a gyermekek sérelmére elkövetett bűncselekmények, tiltott kábítószer-kereskedelem és tiltott fegyverkereskedelem, korrupció, csalás) nem minősült egy taxatív felsorolásnak, az „így különösen” kitétel arra utalt, hogy az Unió egyéb deliktumok ellen is felléphetett. ${ }^{71}$ A Szerződés szövegének ellentmondásai miatt tehát kérdéses volt, hogy az Európai Unió jogharmonizációs hatásköre a Szerződés szövegét szó szerint interpretálva kizárólag a 31. cikk e) pontjában felsorolt három büncselekmény vonatkozásában állt fenn, vagy pedig a 31 . cikket a 29. cikkel összhangban értelmezve egyéb deliktumokra is kiterjedhetett. ${ }^{72}$ A jogtudomány képviselőinek többsége a tágabb értelmezés mellett foglalt állást, ${ }^{73}$ és hasonló álláspontot képviselt az uniós jogalkotó is, hiszen a Lisszaboni Szerződés hatálybalépéséig számos olyan III. pilléres jogforrást fogadott el, amelyek a tagállamok büncselekményi tényállásainak és szankcióinak közelítését célozták. ${ }^{74}$

A 2009-ben hatályba lépett Lisszaboni Szerződés eltörölte az Európai Unió pilléres struktúráját, és kifejezett jogharmonizációs hatáskörökkel ruházta fel az Uniót a büntetőjog területén. Az Európai Unió anyagi büntetőjogi jogharmonizációs hatáskörének részletes szabályait az EUMSZ 83. cikke tartalmazza: a 83. cikk (1) bekezdése egyes különösen súlyos, határokon átnyúló bủncselekmények tényállásainak harmonizációját teszi lehetővé, a 83. cikk (2) bekezdése pedig az uniós politikák eredményes végrehajtásához szükséges büntetőjogi jogharmonizációról rendelkezik.

Az EUMSZ 83. cikk (1) bekezdése értelmében a Bizottság javaslatára az Európai Parlament és a Tanács rendes jogalkotási eljárás keretében elfogadott irányelvekben szabályozási minimumokat állapíthat meg a büncselekményi tényállások és a büntetési tételek meghatározására. Irányelvek elfogadására olyan, különösen súlyos büncselekmények esetében kerülhet sor, amelyek jellegüknél vagy hatásuknál fogva több államra kiterjedő vonatkozásúak, vagy amelyek esetében különösen szükséges, hogy az ellenük folytatott küzdelem közös alapokon nyugodjék. Az EUMSZ meghatározza azt a tíz, ún. uniós dimenziójú büncselekményt, amelyek vonatkozásában lehetőség van a tényállások és a büntetési tételek harmonizációjára.

69 SATZger, Helmut: Das Strafrecht als Gegenstand europäischer Gesetzgebungstätigkeit. Kritische Vierteljahresschrift für Gesetzgebung und Rechtswissenschaft, 1/2008, 18-19.

70 Peers (2004): i. m., 206.

71 Peers (2011): i. m., 756; Mitsilegas: i. m., 85.

72 CAlliess, Christian: Die neue Europäische Union nach dem Vertrag von Lissabon. Mohr Siebeck, Tübingen, 2010, 454.

73 Lásd például CALLIES: i. m., 454-455; HECKER, Bernd: Sind die nationalen Grenzen des Strafrechts überwindbar? Die Harmonisierung des materiellen Strafrechts in der Europäischen Union. Juristische Arbeitsblätter, 8-9/2007, 565-566; Mitsilegas: i. m., 85-86; SATZger, Helmut: Akzeptanz europäischen Strafrechts. Normative Vorkehrungen auf europäischer Ebene für eine Akzeptanzsicherung europäischen Strafrechts in den Mitgliedstaaten. In: Hochloch, Gerhard (Hrsg.): Wege zum Europäischen Recht. Nomos, Baden-Baden, 2002, 58; Vogel, Joachim: Begriffe und Ziele der Harmonisierung. In: Böse, Martin (Hrsg.): Europäisches Strafrecht mit polizeilicher Zusammenarbeit. Nomos, Baden-Baden, 2013, 272.

74 Bővebben lásd Miettinen, Samuli: Criminal Law and Policy in the European Union. Routledge, London-New York, 2013, 35-37; PEERS (2011): i. m., 25-29, 756-758. 
Ezek a büncselekmények a következők: terrorizmus, emberkereskedelem, nök és gyermekek szexuális kizsákmányolása, tiltott kábítószer-kereskedelem, tiltott fegyverkereskedelem, pénzmosás, korrupció, pénz és egyéb fizetőeszközök hamisítása, számítógépes bűnözés, szervezett bünözés. Fontos kiemelni, hogy a felsorolás nem taxatív, a bünözés alakulásának függvényében a Tanács határozatban egyéb büncselekményeket is bevonhat ebbe a körbe. Erröl a Tanács az Európai Parlament egyetértését követően, egyhangúlag határoz.

Az EUMSZ 83. cikk (2) bekezdése egy kiegészítő harmonizációs hatáskört („,Annexkompetenz") ${ }^{75}$ állapít meg. $\mathrm{E}$ rendelkezés lényegében az Európai Bíróság joggyakorlatát intézményesítette. ${ }^{76} \mathrm{~A}$ generálklauzula értelmében, ha valamely, harmonizációs intézkedések hatálya alá tartozó területen az Unió politikájának eredményes végrehajtásához elengedhetetlen a tagállamok büntetöügyekre vonatkozó törvényi, rendeleti és közigazgatási rendelkezéseinek közelítése, irányelvekben szabályozási minimumokat lehet megállapítani e területen a büncselekményi tényállásokra és a büntetési tételekre vonatkozóan. A Szerződés e rendelkezése az Európai Unió céljainak elérése érdekében valamennyi közös politika területén generálisan lehetővé teszi a büntetöjogi eszközök alkalmazását, amennyiben az elengedhetetlen, nélkülözhetetlen az adott politika eredményes végrehajtásához. E kiegészitő harmonizációs hatáskör alkalmazásának feltétele, hogy az adott szakpolitika harmonizációs intézkedések hatálya alá essen. Ez azt jelenti, hogy az adott területen az Unió korábban már fogadott el olyan intézkedést, amely a tagállamok nemzeti jogának harmonizációjára irányul. Az alkalmazás másik feltétele, hogy a jogharmonizáció elengedhetetlen legyen az Unió adott politikájának eredményes végrehajtásához. Ezen feltétel értelmében büntetőjogi szankció csak akkor alkalmazható, ha az adott uniós szakpolitika végrehajtása a rendelkezésre álló eszközökkel nem eredményes, nem hatékony. A 83. cikk (2) bekezdésének alkalmazása során az uniós jogalkotónak mérlegelnie kell, hogy a büntetőjogi szankciók elösegítik-e az adott uniós szakpolitika eredményes végrehajtását, hogy a büntetöjogi szankciók hatékonyabbak-e, mint az egyéb, nem büntetőjogi szankciók, valamint hogy a büntetőjogi szankciók arányosak-e, vagyis a szankciók alkalmazásával járó hátrányok nem haladják-e meg az uniós szakpolitika hatékony végrehajtásával járó előnyöket. ${ }^{77}$

\subsection{Szupranacionális jogalkotási hatáskör}

Szupranacionális jogalkotási hatáskörröl akkor beszélhetünk, ha az Európai Unió külön belső jogi aktus nélkül valamennyi tagállamban közvetlenül alkalmazható büntetőjogi normákat alkot. Míg a jogharmonizáció legfőbb eszköze az irányelv (és korábban a III. pilléres kerethatározat), amelyet a nemzeti jogalkotónak át kell ültetnie

75 Ambos: i. m., 558; Hecker (2012): i. m., 259; Safferling: i. m., 415; Satzger (2013): i. m., 124.

76 C-176/03. sz., Bizottság kontra Tanács ügyben 2005. szeptember 13-án hozott ítélet (ECLI:EU:C:2005:542); C-440/05. sz., Bizottság kontra Tanács ügyben 2007. október 23-án hozott ítélet (ECLI:EU:C:2007:625).

77 ÖBERG, Jacob: Union Regulatory Criminal Law Competence after Lisbon Treaty. European Journal of Crime, Criminal Law and Criminal Justice, Vol. 19/4, 2011, 292-293, 313-314. 
a belső jogba, addig a szupranacionális jogalkotás rendeleti úton történik. A jogharmonizációs és a szupranacionális jogalkotási hatáskör közötti alapvető különbség tehát az, hogy az előbbi esetében az irányelvben büntetendőnek nyilvánított magatartás elkövetőjét az azt átültető, implementáló belső jog alapján lehet felelősségre vonni, az utóbbi esetében viszont az elkövető felelőssége közvetlenül az uniós jog, a rendelet alapján mondható ki. ${ }^{78}$

A Lisszaboni Szerződést megelőzően az Európai Unió az általános vélekedés szerint nem rendelkezett szupranacionális büntetőjogi jogalkotási hatáskörrel. ${ }^{79}$ Ezzel szemben azonban voltak olyan vélemények, amelyek szerint számos olyan szerződési rendelkezés található, amelyből kiterjesztő értelmezés segítségével a szupranacionális büntetőjogi hatáskörök is levezethetök. Ilyenkor a beleértett hatáskörök (implied powers) elve alapján, az adott területen fennálló közösségi hatáskörbe az abból következő, de konkrétan nem nevesített büntetőjogi hatáskört is bele kell érteni. ${ }^{80}$ Ilyen lehetséges jogalapokat tartalmazott az EK Szerződés többek között a közös agrárpolitika, ${ }^{81}$ a közös közlekedéspolitika, ${ }^{82}$ a versenyjog, ${ }^{83}$ a vámügyi együttmüködés, ${ }^{84}$ a közös környezetvédelmi politika, ${ }^{85}$ illetve a Közösség pénzügyi érdekeinek védelme ${ }^{86}$ területén. ${ }^{87} \mathrm{E}$ tárgykörök esetén a Szerződés csak azt rögzítette, hogy az Unió az adott politika vagy célkitüzés végrehajtása érdekében minden „szükséges” vagy „megfelelo" intézkedés elfogadására jogosult. Ez olyan tág jogalkotási hatáskört biztosított az uniós jogalkotónak, amely a szoros tárgyi összefüggés, vagy a szükséges járulékos intézkedések miatt e szerzők álláspontja alapján akár büntetőjogi természetű normák kibocsátását is megalapozhatta. ${ }^{8}$ Ezen kiterjesztő értelmezést azonban a gyakorlatban az uniós jogalkotó nem tette magáévá, így a Lisszaboni Szerződést megelőzően nem születtek olyan uniós dokumentumok, amelyek a tagállamokban közvetlenül alkalmazandó büntetőjogi normákat tartalmaztak volna.

A Lisszaboni Szerződés ugyanakkor az EUMSZ 83. cikkében rögzített jogharmonizációs hatáskör mellett szupranacionális büntetőjogi jogalkotási hatáskörrel is felruházza az Európai Uniót. Ezt a jogalapot az EUMSZ 325. cikk (4) bekezdése tartalmazza, amely az Európai Unió pénzügyi érdekeit sértő csalások elleni küzdelemről rendelkezik. Eszerint az Európai Parlament és a Tanács rendes jogalkotási eljárás keretében és a Számvevőszékkel folytatott konzultációt követően meghozza

78 SAtzger (2013): i. m., 93-94, 135-136.

79 Lásd például CALLIES: i. m., 456; DoRRA, Fabian: Strafrechtliche Legislativkompetenzen der Europäischen Union. Eine Gegenüberstellung der Kompetenzlage vor und nach dem Vertrag von Lissabon. Nomos, Baden-Baden, 2013, 99; Hecker (2012): i. m., 147; SATZger (2008): i. m., 20.

80 HECKER (2012): i. m., 148.

81 EK Szerződés 34. cikk (2) bekezdés és 37. cikk (2) bekezdés.

82 EK Szerződés 71. cikk (1) bekezdés $d$ ) pont, 75 cikk (3) bekezdés és 80 . cikk (2) bekezdés.

83 EK Szerződés 83. cikk (1)-(2) bekezdés.

84 EK Szerződés 135. cikk.

85 EK Szerződés 175. cikk (1) bekezdés.

86 EK Szerződés 280. cikk (4) bekezdés.

87 Dorra: i. m., 101-108; Fletcher-LöÖF-Gilmore: i. m., 176; SATZger (2008): i. m., 20.

88 SZALAYNÉ SÁNDOR Erzsébet: A büntetőjogi hatalom megítélése az Európai Bíróság gyakorlatában: az uniós, a közösségi és a tagállami hatáskörök versengése. Belügyi Szemle, 2004/5, 29-30. 
az Unió pénzügyi érdekeit sértő csalások megelőzése és az azok elleni küzdelem terén a szükséges intézkedéseket azzal a céllal, hogy hathatós és azonos mértékü védelmet nyújtsanak a tagállamokban, valamint az Unió intézményeiben, szerveiben és hivatalaiban. A 83. cikkel ellentétben a 325. cikk nem utal a jogforrási formára, mindössze annyit mond, hogy az uniós jogalkotó minden „szükséges intézkedést” meghozhat, beleértve a büntetőjogi eszközöket is. ${ }^{89}$ Ebböl következik, hogy az uniós jogalkotó irányelvek helyett a tagállamokban közvetlenül alkalmazható rendeletek elfogadására is jogosult, amivel megnyílt az út, hogy az uniós jogalkotó - szük körben, a pénzügyi érdekek védelmét érintően - szupranacionális büntetőjogi tényállásokat fogadjon el. ${ }^{90}$

\section{3. Összegzés}

Bár a büntetőjog csak 2009-ben, a Lisszaboni Szerződés hatálybalépésével foglalta el az őt megillető helyet az Unió politikái között, már ezt megelőzően sem tudta függetleníteni magát a közösségi/uniós jog befolyása alól. Az uniós jog egyfelöl a tagállam uniós joggal összeegyeztethetetlen büntetőjogi normáinak semlegesítésével negatív, másfelől pedig az asszimiláció elve, a kerettényállások, a jogharmonizáció és a szupranacionális jogalkotás révén pozitív hatást gyakorol a tagállamok büntetőjogára.

Az uniós jog nemzeti büntetőjogra gyakorolt hatása különböző intenzitású lehet. A tagállamok büntetőjogára a legenyhébb befolyást az asszimiláció elve és a kerettényállások jelentik, mivel ezek nem járnak a nemzeti jogok egymáshoz közelítésével, valamilyen közös normaanyag elfogadásával és átültetésével. Ebben az esetben mindössze az uniós és a tagállami jog egymásra utalására kerül sor, oly módon, hogy vagy a büntetőjogi tényállások hatályát terjesztik ki az uniós jogtárgyak védelmére, vagy pedig a bűncselekmény elkövetési magatartását határozzák meg az uniós jogra hivatkozva. A jogharmonizáció során már valamilyen uniós szintü közös szabályozás átvételére kerül sor, amely a nemzeti büntetőjogok közötti különbségek kiküszöbölését célozza. E három módszerben közös, hogy a büntetőjogi felelősségre vonás végső soron a nemzeti büntetőjogi normák alapján történik. Ezzel szemben a tagállamok szuverenitását legdrasztikusabban érintő szupranacionális büntetőjogi jogalkotás esetén a tagállamokban közvetlenül alkalmazandó uniós normák elfogadására kerül sor, amelynek következtében a felelősségre vonás alapjául már e szupranacionális tényállások szolgálnak.

89 SATZger, Helmut: Art. 325 AEUV. In: Streinz, Rudolf (Hrsg.): EUVIAEUV. Vertrag über die Europäische Union und Vertrag über die Arbeitsweise der Europäischen Union. C. H. Beck, München, 2012, 2629; ScHоO, Johann: Artikel 325 AEUV. In: Schwarze, Jürgen (Hrsg.): EU-Kommentar. Nomos, Baden-Baden, 2012, 2482; FROMm, Ingo Erasmus: EG-Rechtssetzungsbefugnis im Kriminalstrafrecht. Der Schutz der finanziellen Interessen der EG nach der neuesten Rechtsprechung des EuGH sowie im Lissabonner Vertrag. Nomos, Baden-Baden, 2009, 65-67.

90 Hecker (2012): i. m., 493; Safferling: i. m., 409; Satzger (2013): i. m., 104. 
A Lisszaboni Szerződést megelözően a Közösség kifejezett büntetőjogi hatásköreinek hiánya miatt a közösségi jog elsősorban közvetett módon, az asszimilációs kötelezettség és a kerettényállások útján tudott a nemzeti büntetőjogokra hatni. Szupranacionális jogalkotási hatáskörrel az Unió egyáltalán nem rendelkezett, és a büntetőjogi jogharmonizáció terepe is elsődlegesen a III. pilléres együttmüködés volt. A Szerződés kifejezett büntetőjogi hatáskörökkel ruházta fel az uniós jogalkotót, ami az Unió büntetőjogi aktivitása növekedését vonta maga után. Ma ez még elsösorban a büntetőjogi jogharmonizációs hatáskör gyakorlását jelenti, a szerződéses felhatalmazás ellenére a szupranacionális jogalkotási hatáskör alkalmazására mind ez idáig még nem került sor. Ez azonban várhatóan csak idő kérdése. Az Európai Unió büntetőjoga ugyanis egy dinamikusan fejlődő, folyamatosan alakuló és bővülő jogterület, így nyugodtan mondhatjuk, hogy az uniós jog nemzeti büntetőjogokra gyakorolt hatása a jövőben csak még szélesebb körüvé és intenzívebbé válik.

\section{Abstract}

This paper aims to analyse the main linking points between EU law and national criminal law. For a long time, the criminal laws of the Member States have been heavily affected by EU law. This influence can be either negative or positive. The most lenient form of the positive effect is the assimilation principle, which does not seek to incorporate EU norms into national criminal law, only attempts to extend the latter's applicability to the protection of the interests of the European Union. In the case of legal harmonization the Member States are required to adopt common criminal norms which aim to reduce the differences of the national criminal law systems. The most serious impact on national penal law is the supranational criminal legislation, which results not only in the approximation but the unification of the criminal laws of the Member States. 